\title{
Pengaruh Organizational Justice Dan Religiosity Terhadap Employee Fraud Dengan Dimediasi Whistleblowing Intention
}

\author{
Erine Saskia Anggraini ${ }^{*}{ }^{*}$, Reskino ${ }^{2}$ \\ 1, 2Universitas Islam Negeri Syarif Hidayatullah Jakarta \\ 'erine.saskia@gmail.com \\ ${ }^{*}$ Penulis korespondensi
}

\begin{abstract}
This study aims to examine the influence of organizational justice and religiosity on employee fraud mediated by whistleblowing intention. This study uses primary data by distributing questionnaires to employees who work in Islamic banks in the DKI Jakarta area. Sampling was done using the purposive sampling method. This study used sample of 71 respondents. The data analysis method that used as Partial Least Square (PLS)-SEM with the help of data analysis tool SmartPLS 3.0. The results of this study indicate that religiosity shows significant effect on whistleblowing intentions. Organizational justice unable to contribute significantly to whistleblowing intention. Whistleblowing intention have a significant effect on employee fraud. Organizational justice and religiosity unable to contribute significantly to the employee fraud. Furthermore, religiosity significantly influence on employee fraud through whistleblowing intentions. Organizational justice unable to contribute significantly to employee fraud through whistleblowing intentions.
\end{abstract}

Keywords: Organizational Justice, Religiosity, Whistleblowing Intention, Employee Fraud

\begin{abstract}
Abstrak
Penelitian ini dilakukan untuk menguji pengaruh organizational justice dan religiosity terhadap employee fraud dengan dimediasi whistleblowing intention. Penelitian ini menggunakan data primer dengan menyebarkan kuesioner kepada karyawan yang bekerja di bank syariah di wilayah DKI Jakarta. Pengambilan sampel dilakukan dengan menggunakan metode purposive sampling. Penelitian ini menggunakan sampel sebanyak 71 responden. Penelitian ini menggunakan metode analisis data yaitu Partial Least Square (PLS)-SEM dengan menggunakan alat analisis data yaitu SmartPLS 3.0. Hasil penelitian ini menunjukkan bahwa religiosity berpengaruh secara signifikan terhadap whistleblowing intention. Organizational justice belum dapat berkontribusi secara signifikan terhadap whistleblowing intention. Whistleblowing intention berpengaruh secara signifikan terhadap employee fraud. Organizational justice dan religiosity belum mampu berpengaruh secara signifikan terhdap employee fraud. Selanjutnya, religiosity berpengaruh secara signifikan terhadap employee fraud melalui whistleblowing intention. Organizational justice belum dapat berkontribusi secara signifikan terhadap employee fraud melalui whistleblowing intention.
\end{abstract}

Kata Kunci: Organizational Justice, Religiosity, Whistleblowing Intention, Employee Fraud 


\section{PENDAHULUAN}

Indonesia dengan jumlah populasi penduduk muslim tertinggi dunia memiliki potensi besar pada perkembangan industri perbankan syariah. Bank syariah di Indonesia telah ada sejak tahun 1991, ditandai dengan berdirinya bank syariah pertama yaitu Bank Muamalat Indonesia. Hingga saat ini, industri perbankan syariah berkembang sangat pesat ditandai dengan adanya 14 Bank Umum Syariah dan 20 Unit Usaha Syariah dan 164 Bank Pembiayaan Rakyat Syariah (Otoritas Jasa Keuangan, 2019). Dengan semakin besarnya industri perbankan syariah di Indonesia, maka semakin besar pula tantangan yang dihadapi oleh bank syariah. Menurut Nwankwo (1991), fraud adalah musuh nomor satu dunia bisnis (Balogun, Selemogwe, \& Akinfala, 2013).

Menurut hasil survei yang dilakukan oleh Association of Certified Fraud Examiners (ACFE) yang termuat dalam Report to The Nation: 2020 Global Study on Occupational Fraud and Abuse, menunjukkan bahwa terjadi 2.504 kasus fraud di 125 negara, dengan total kerugian mencapai lebih dari \$3.6 milyar. Sedangkan laporan ACFE dalam edisi Asia Pasifik, Indonesia memiliki kasus fraud paling banyak di wilayah Asia Pasifik dengan jumlah kasus sebanyak 36 kasus fraud dari total 198 kasus fraud yang ada di wilayah Asia Pasifik (ACFE, 2020). Hal ini menunjukkan bahwa kasus fraud yang ada di Indonesia cukup banyak terjadi. Pada laporan yang sama, kasus fraud paling banyak terjadi di tingkat employee dengan persentase $41 \%$. Hal ini mengindikasikan bahwa fraud paling banyak terjadi di tingkat employee. Tingginya jumlah penipuan oleh karyawan adalah kekhawatiran besar yang dapat berdampak negatif pada neraca, kepercayaan klien, dan moral staf (Ramazani \& Atani, 2010; Skousen \& Wright, 2006; Said, Alam, Ramli, \& Rafidi, 2017). Para ahli umumnya setuju bahwa penipuan karyawan di perbankan terus menjadi perhatian utama bagi organisasi dari semua ukuran dan di semua wilayah (PWC, 2005; Klein, 2015; Said et al., 2017).

Dari data Report to The Nation: 2018 Global Study on Occupational Fraud And Abuse Asia Pasific Edition tahun 2018 menunjukan bahwa industri perbankan dan jasa keuangan menempati posisi ke-2 sebagai industri yang paling banyak mengalami kasus fraud dengan jumlah 25 kasus (11\%), dan kerugian yang diderita akibat fraud yaitu sebesar \$310.000. KPMG (2013) meneliti prevalensi pelanggaran di industri. Survei menunjukkan bahwa 71\% karyawan yang bekerja di perbankan dilaporkan telah "melihat secara personal" atau "mengetahui langsung" tentang fraud dalam organisasi mereka selama 12 bulan terakhir. Fraud universe di lembaga perbankan sangat ekspansif (Sanusi, Rameli, \& Isa, 2015). Kepala Eksekutif Pengawas Perbankan OJK, Heru Kristiyana juga menyatakan penipuan (fraud) yang sulit dideteksi di perbankan adalah kecurangan yang dilakukan oleh karyawan perusahaan dengan nasabah (Fauzi, 2020). Hal ini dikarenakan kecurangan oleh karyawan dilakukan oleh orang dalam organisasi itu sendiri yang paham celah fraud yang ada. Hal ini dapat dilihat dari banyaknya kasus fraud yang melibatkan pegawainya sendiri.

Pada tahun 2015, Bank Syariah Mandiri (BSM) merugi Rp 50 miliar akibat aksi penggelapan dan pemalsuan dokumen. Pelakunya terdiri dari empat orang, termasuk dua di antaranya adalah orang dalam alias pegawai bank itu sendiri (Kartika, 2015). Terdapat 
juga satu kasus fraud yang terjadi di BJB Syariah pada tahun 2017 yaitu kasus dugaan kredit fiktif yang merugikan perseroan senilai Rp548 miliar yang melibatkan pegawai tetap perusahaan (Arief, 2019). Salah satu faktor yang mempengaruhi seseorang melakukan tindakan fraud adalah tidak terpenuhinya keadilan dalam organisasi. Tidak terpenuhinya keadilan di dalam organisasi tempat karyawan bekerja dapat memicu terjadinya kecurangan (Sumbayak, 2017; Yuliana, 2016). Kebijakan perusahaan mengenai alokasi penghargaan dan prosedur dalam perusahaan yang belum dapat memenuhi rasa keadilan bagi setiap karyawannya dapat memicu terjadinya tindakan employee fraud.

Selanjutnya rendahnya religiusitas seseorang menjadi salah satu faktor terjadinya fraud. Agama dipandang sebagai fakta nyata dari pengalaman manusia dan diyakini sebagai faktor yang berpengaruh dalam pengembangan kepribadian individu, dan bagian penting dari kehidupan (Said, Karim, \& Johari, 2018). Rendahnya religiusitas dalam diri seseorang menyebabkan nilai-nilai agama diabaikan dan berpotensi melakukan tindakan illegal ataupun tidak bermoral.

Whistleblowing merupakan salah satu cara yang dapat digunakan untuk mencegah terjadinya fraud dalam suatu perusahaan. Berdasarkan Report to The Nation: 2020 Global Study on Occupational Fraud and Abuse yang diterbitkan oleh Association of Certified Fraud Examiners (2020) mengungkapkan tips (informasi yang diberikan secara sembunyisembunyi) dari tahun ke tahun selalu menjadi peringkat teratas sumber pengungkapan kecurangan. Di mana separuh dari sumber tips berasal dari employee, yaitu sejumlah 50\% tips dilaporkan ataupun berasal dari karyawan perusahaan itu sendiri.

Penelitian sejenis yang membahas mengenai organizational justice dan religiosity terhadap fraud telah dilakukan menunjukkan hasil yang berbeda (Sumbayak, 2017; Yuliana, 2016; Pristiyanti, 2012; I. Indriani et al., 2016; Fathi et al., 2017; Pamungkas, 2014; Zamzam et al., 2017). Selain itu, pada penelitian sebelumnya belum terdapat penelitian yang spesifik membahas mengenai pengaruh organizational justice dan religiosity terhadap employee fraud dengan dimediasi whistleblowing intention.

Faktor keadilan organisasi secara signifikan terkait dengan whistleblowing, karena sering dipandang sebagai kewajiban moral dan perilaku etis (Murray, 2010). Keadilan organisasi dapat berdampak pada perilaku whistleblowing karena meningkatkan motivasi prososial karyawan (Bass \& Riggio, 2006), yang terkait dengan whistleblowing intention (Ugaddan \& Park, 2018). Hasil pnelitian yang dilakukan oleh Ugaddan \& Park (2018) menunjukkan bahwa terdapat hubungan positif dan signifikan antara organizational justice dengan whistleblowing intention. Namun hasil penelitian yang dilakukan oleh Wulansari (2019) menunjukkan bahwa keadilan dalam oragnisasi tidak berpengaruh terhadap whistleblowing intention. Berdasarkan ketidakkonsistenan penelitian sebelumnya, maka dirumuskan hipotesis penelitian sebagai berikut:

$\mathbf{H}_{\mathbf{1}}$ : Organizational justice berpengaruh secara signifikan terhadap whistleblowing intention.

Fernando dan Jackson (2006) mengemukakan bahwa individu yang beragama cenderung akan berperilaku sesuai dengan nilai-nilai yang melekat dalam agama tersebut, dan tidak 
akan menyetujui perilaku yang tidak berprinsip, maka kemungkinan untuk melakukan whistleblowing ketika berhadapan dengan situasi yang tidak etis sangat tinggi. Penelitian terebut sejalan dengan penelitian yang dilakukan oleh Puni, Agyemang, \& Asamoah (2016) yang menunjukkan bahwa religiosity dapat mempengaruhi whistleblowing intention. Namun penelitian yang dilakukan oleh Soni, Maroun, \& Padia (2015) menunjukah bahwa tidak terdapat pengaruh yang signifikan antara religiosity dengan niat melakukan whistleblowing. Berdasarkan ketidakkonsistenan penelitian sebelumnya, maka dirumuskan hipotesis penelitian sebagai berikut:

$\mathbf{H}_{2}$ : Religiosity berpengaruh secara signifikan terhadap whistleblowing intention.

Menurut Gilliland (1993), persepsi karyawan tentang ketidakseimbangan antara masukan (pengetahuan, keterampilan, kemampuan, pengalaman, kerajinan, maupun kegigihan dan kerja keras) yang mereka berikan dengan hasil yang mereka terima (gaji, perlakuan ataupun pengakuan) akan menghasilkan emosi negatif yang memotivasi karyawan untuk mengubah perilaku, sikap, dan kepuasan mereka (Yuliana, 2016). Penelitian yang dilakukan oleh Sumbayak (2017); Yuliana, (2016) menunjukkan bahwa keadilan organisasi berpengaruh terhadap fraud. Namun, hasil penelitian yang dilakukan oleh Pristiyanti (2012) dan I. Indriani et al., (2016) menunjukkan bahwa tidak terdapat pengaruh antara keadilan organisasi terhadap fraud. Berdasarkan ketidakkonsistenan penelitian sebelumnya, maka dirumuskan hipotesis penelitian sebagai berikut:

$\mathbf{H}_{3}$ : Organizational justice berpengaruh secara positif terhadap employee fraud.

Rest et al. (1969) dalam menjelaskan bahwa religius personal merupakan titik awal untuk menemukan perbedaan judgment moral, karena ideologi religius memberikan banyak penjelasan mengenai judgment individu tentang salah dan benar. Al-Khalifah (1994) dalam penelitiannya menyebutkan bahwa religiusitas, dalam konteks Islam, berfungsi sebagai mekanisme yang melindungi orang dari godaan kriminal, dengan menempatkan konsep hukum dalam yurisdiksi agama (Said et al., 2018). Hal tersebut sejalan dengan penelitian yang dilakukan oleh Fathi et al., (2017), Pamungkas (2014), dan Zamzam, Mahdi, \& Ansar (2017), menunjukkan hasil bahwa religiusitas berpengaruh terhadap kecurangan. Berdasarkan penjelasan tersebut, maka dirumuskan hipotesis penelitian sebagai berikut: $\mathbf{H}_{4}$ : Religiosity berpengaruh secara signifikan terhadap employee fraud.

Adanya whistleblowing dalam suatu peruasahaan merupakan bentuk pengawasan. Karyawan menjadi takut untuk melakukan kecurangan karena sistem ini bisa digunakan oleh seluruh karyawan, sehingga sesama karyawan menjadi saling mengawasi satu sama lain dan takut untuk dilaporkan karyawan lain karena melakukan kecurangan (Utari, Sujana, \& Yuniarta, 2019). Hasil penelitian yang dilakukan oleh Utari et al. (2019), Dewi, Dewi, \& Sujana (2018) dan Nurharjanti (2017) menunjukkan bahwa whistleblowing berpengaruh negatif dan signifikan terhadap fraud. Namun, penelitian yang dilakukan oleh Lutfi \& Biduri (2014) menunjukkan bahwa tidak ada pengaruh antara whistleblowing 
dengan fraud. Berdasarkan penjelasan tersebut, maka dirumuskan hipotesis penelitian sebagai berikut:

$\mathbf{H}_{5}$ : Whistleblowing intention berpengaruh secara signifikan terhadap employee fraud.

Apabila karyawan merasakan perlakuan yang adil di dalam organisasi tempat ia bekerja maka akan tercipta lingkungan kerja yang kondusif dan tidak ada kecemburuan antar karyawan. Sehingga dapat mengurangi tekanan atau motivasi untuk melakukan tindakan fraud. Penelitian yang dilakukan oleh Kurniawan et al., (2018) menunjukkan bahwa keadilan organisasi memiliki pengaruh terhadap niat melakukan whistleblowing. Sehingga dengan adanya keadilan organisasi dapat mendorong individu melakukan whistleblowing dan menurunkan tingkat kecurangan. Berdasakan uraian tersebut dapat disimpulkan bahwa keadilan organisasi dan whistleblowing intention berpengaruh terhadap employee fraud, maka hipotesis yang dirumuskan dalam penelitian ini sebagai berikut:

$\mathbf{H}_{6}$ : Organizational Justice berpengaruh secara signifikan terhadap employee fraud melalui whistleblowing intention sebagai variabel intervening.

Manusia yang memiliki level religiusitas yang tinggi akan lebih empati dan memperhatikan kepentingan orang lain (Hood et al, 1996), serta religiusitas akan memberikan kontribusi terhadap idealisme seseorang. Individu yang memiliki religiusitas yang tinggi tidak akan melakukan tindakan kecurangan karena hal tersebut melanggar norma. Hasil penelitian Puspitosari (2019) menunjukkan bahwa individu yang memiliki nilai religiusitas tinggi cenderung akan melaporkan pelanggaran. Oleh karena itu dengan religiusitas yang tinggi seseorang cenderung akan memiliki niat whistleblowing sehingga menurunkan tingkat kecurangan. Berdasakan uraian tersebut dapat disimpulkan bahwa religiosity dan whistleblowing intention berpengaruh terhadap employee fraud, maka hipotesis yang dirumuskan dalam penelitian ini sebagai berikut:

$\mathbf{H}_{7}$ : Religiosity berpengaruh secara signifikan terhadap employee fraud melalui whistleblowing intention sebagai variabel intervening.

\section{METODE}

Penelitian ini merupakan penelitian kuantitatif menggunakan data primer. Populasi dalam penelitian ini yaitu karyawan bank syariah, sedangkan sampel yang digunakan dalam penelitian ini adalah karyawan bank syariah wilayah DKI Jakarta. Dalam penelitian ini, peneliti menggunakan metode pemilihan sampel yaitu purposive sampling, dengan kualifikasi yaitu, (1) karyawan bank syariah wilayah DKI Jakarta, (2) karyawan yang memiliki pengalaman kerja minimal 1 tahun, karena dianggap telah memiliki pengalaman yang cukup untuk memahami internal perusahaan. Setelah dilakukan penyebaran kuesioner melalui Google Form, diperoleh sampel sebanyak 71 responden.

Dalam penelitian ini untuk variabel organizational justice menggunakan instrumen yang dikembangkan oleh Collquit (2001), Rae \& Subramaniam, (2008) dan Kristanto 
(2015) menggunakan 8 indikator yaitu (1) Kompensasi sesuai dengan pekerjaan, (2) Kompensasi sesuai dengan kinerja, (3) Pemberian penghargaan, (4) Kesamaan pelaksanaan keputusan perusahaan, (5) Kesempatan dalam menyuarakan pendapat, (6) Perlakuan atasan terhadap karyawan, (7) Keterbukaan atasan kepada bawahan, dan (8) Kompensasi sesuai dengan prestasi. Variabel religiosity mengadopsi indikator dari Fathi et al., (2017), menggunakan enam indikator religiusitas muslim yaitu (1) Keyakinan, (2) Praktik ibadah, (3) Kesetiaan, (4) Pengalaman, (5) Pengetahuan, (6) Pengabdian dan konsekuensi. Variabel whistleblowing intention diukur dengan menggunakan indikator yang dikembangkan oleh Bagustianto \& Nurkholis (2015), antara lain yaitu (1) Niat/minat melakukan tindakan whistleblowing, (2) Keinginan untuk mencoba melakukan tindakan whistleblowing, (3) Rencana untuk melakukan tindakan whistleblowing, (4) Usaha keras untuk melakukan internal whistleblowing, dan (5) Usaha keras untuk melakukan eksternal whistleblowing. Serta variabel employee fraud mengadopsi indikator dari yang dikembangkan oleh Said, Alam, Ramli, \& Rafidi (2017) yang terdiri dari lima indikator yaitu, (1) Penyalahgunaan aset atau sumber daya organisasi, (2) Penyalahgunaan waktu kantor, (3) Terlibat dalam kecurangan, (4) Ketidakpatuhan pada kebijakan, dan (5) Mencuri uang tunai atau setara kas.

Metode pengujian dalam penelitian ini terdiri dari: (1) Statistik deskriptif, (2) uji outer model (convergent validity, discriminant validity dan reliability), (3) uji inner model (R-Square, Q-square, Goodness of Fit, dan uji hipotesis), (4) uji efek intervening.

\section{HASIL DAN PEMBAHASAN}

\section{Statistik Deskriptif}

Penelitian ini menggunakan data primer yang diperoleh melalui penyebaran kuesioner melalui Google Form. Jumlah sampel pada penelitian ini yaitu sebanyak 71. Dari hasil uji statistik deskriptif dapat diketahui bahwa standar deviasi dari masing-masing variabel yaitu organizationa justice 5,173, religiosity 4,839, whistleblowing intention 2,949, dan employee fraud 4,725. Nilai tersebut apabila dibandingkan dengan nilai rata-rata dari masing-masing variabel yaitu organizational justice 29,99, religiosity 44,22, whistleblowing intention 21,04, dan employee fraud 29,37, sehingga dapat dilihat bahwa nilai ratarata dari masing-masing variabel lebih besar daripada standar deviasi. Hal tersebut menunjukkan bahwa kualitas data data dalam penelitian ini baik. Berdasarkan hasil uji statistik deskriptif di atas juga dapat diambil kesimpulan bahwa rata-rata jawaban responden untuk variabel organizational justice, religiosity, whistleblowing intention, dan employee fraud adalah setuju.

\section{Model Pengukuran}

\section{Outer Model}

Terdapat kriteria di dalam penggunaan teknik analisis data dengan SmartPLS untuk menilai outer model yaitu Convergent Validity, Discriminant Validity, dan Reliability. Convergent Validity dari model pengukuran reflektif indikator dinilai berdasarkan korelasi antara item 
score atau component score yang diestimasi dengan software SmartPLS. Ukuran reflektif individual dikatakan tinggi jika berkorelasi lebih tinggi dari 0,70 dengan konstruk yang diukur. Namun, menurut Chin (1998) dalam Ghozali (2015) untuk penelitian tahap awal dari pengembangan skala pengukuran nilai loading 0,50 sampai 0,60 dianggap cukup memadai. Oleh karena itu, dalam penelitian ini menggunakan batas loading factor yaitu 0,50. Berikut ini adalah gambar diagram jalur penelitian ini.

\section{Gambar 1 Diagram jalur disertai nilai loading factor}

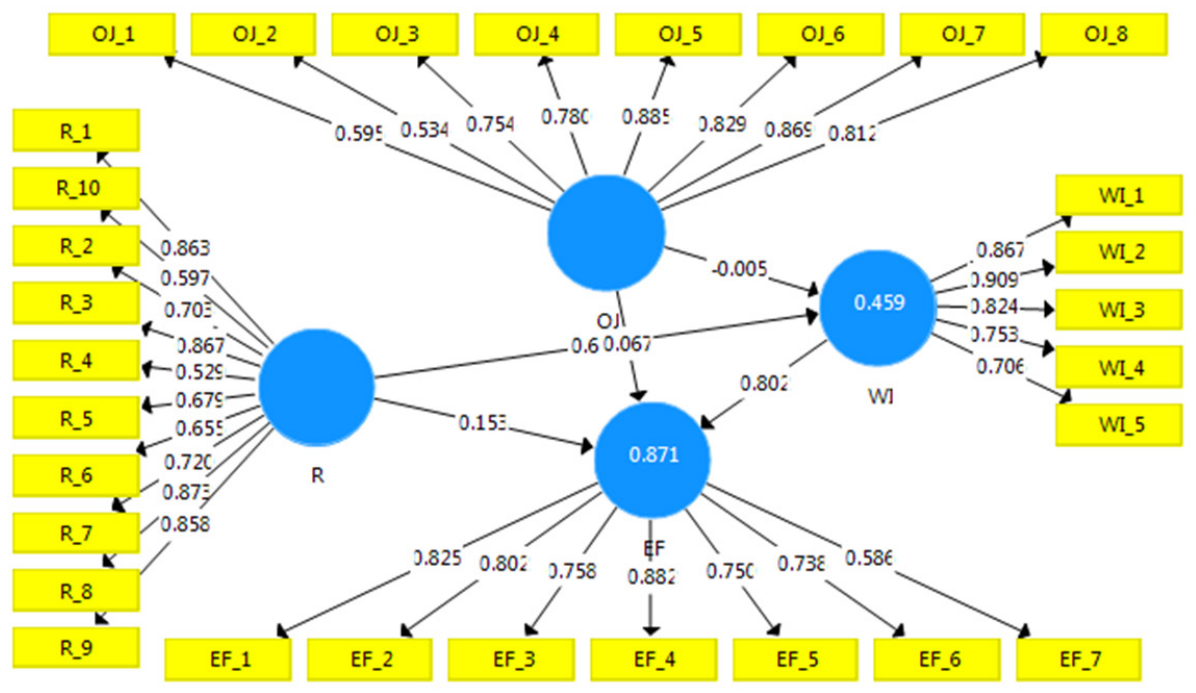

Pengukuran outer model selanjutnya adalah composite reliability dan cronbach alpha. Kriteria reliability dapat dilihat dari nilai composite reliability dan cronbach alpha dari tiap-tiap konstruk. Konstruk dapat dikatakan memiliki reliabilitas yang tinggi apabila mempunyai nilai composite reliability di atas 0,70 dan memiliki nilai cronbach alpha di atas 0,60. Berikut ini adalah tabel composite reliability dan cronbach alpha:

Tabel 1 Composite Reliability dan Cronbach Alpha

\begin{tabular}{lcc}
\hline & Composite Reliability & Cronbach Alpha \\
\hline Organizational Justice & 0,918 & 0,914 \\
Religiosity & 0,924 & 0,908 \\
Whistleblowing Intention & 0,908 & 0,871 \\
Employee Fraud & 0,909 & 0,881 \\
\hline
\end{tabular}

Sumber: hasil olahan data

Tabel 1 menunjukkan nilai composite reliability variabel organizational justice sebesar 0,918, variabel religiosity sebesar 0,924, variabel whistleblowing intention sebesar 0,908, dan variabel employee fraud sebesar 0,909. Nilai composite reliability yang telah disebutkan tadi menunjukkan bahwa seluruh variabel telah memiliki nilai composite reliability di atas 0,70 dan dapat disimpulkan bahwa seluruh konstruk memenuhi kriteria reliabilitas. 
Selanjutnya, cronbach alpha variabel organizational justice sebesar 0,914, variabel religiosity sebesar 0,908, variabel whistleblowing intention sebesar 0,871, dan variabel employee fraud sebesar 0,881. Nilai cronbach alpha yang telah disebutkan tadi menunjukkan bahwa semua variabel telah memiliki nilai cronbach alpha di atas 0,60 sehingga tingkat konsistensi jawaban responden dalam setiap konstruk dapat dikatakan memiliki reliabilitas yang baik.

\section{Inner Model}

Pengujian inner model atau structural model ini dilakukan untuk melihat hubungan antar konstruk nilai signifikan dan $R$-Square dari model penelitian yang dilakukan. Model struktural dievaluasi dengan menggunakan $R$-Square untuk konstruk dependen, uji t, serta signifikansi koefisien jalur struktural. Tabel berikut menyajikan hasil R-Square:

Tabel 2 Nilai R-Square

\begin{tabular}{cc}
\hline & R-Square \\
\hline Whistleblowing Intention & 0,459 \\
Employee Fraud & 0,871 \\
\hline
\end{tabular}

Sumber: hasil olahan data

Tabel 2 menunjukkan nilai $R$-Square dari variabel whistleblowing intention sebesar 0,459 , dan variabel employee fraud sebesar 0,871. Nilai tersebut menunjukkan bahwa variabel organizational justice dan religiosity secara simultan mampu menjelaskan variabel whistleblowing intention sebesar 45,9\%, dan sisanya 54,1\% dijelaskan oleh variabel lain yang tidak dihipotesiskan dalam model Selanjutnya, hasil dari variabel organizational justice religiosity, dan whistleblowing intention mampu menjelaskan variabel employee fraud sebesar $87,1 \%$, dan sisanya 12,9\% dijelaskan oleh variabel lainya yang tidak dihipotesiskan dalam model. Menurut Chin (1998) dalam Ghozali (2015) nilai R-Square tersebut termasuk dalam kategori moderat menuju tinggi.

\section{Hasil Q-Square}

Nilai Q-Square digunakan untuk mengukur seberapa baik nilai observasi dihasilkan oleh model serta estimasi parameternya. Nilai Q-Square diperoleh dari:

$$
\begin{aligned}
Q^{2} & =1-\left(1-R_{1}^{2}\right)\left(1-R_{2}^{2}\right) \\
& =1-\left(1-0,459^{2}\right)\left(1-0,871^{2}\right) \\
& =1-(1-0,2830)(1-0,7586) \\
& =1-(0,7893)(0,2414) \\
& =1-(0,1905) \\
Q^{2} & =0,8095
\end{aligned}
$$


Hasil perhitungan Q-Square tersebut menunjukkan nilai 0,8095 yang berarti bahwa $80,95 \%$ variabel independen dan intervening ini layak untuk menjelaskan variabel dependen yaitu employee fraud.

\section{Hasil Goodness of Fit}

Evaluasi Goodness of Fit (GoF) dilakukan untuk purification dan refinement terhadap uji validitas atau reliabilitas konstruk (Ghozali, 2015), sehingga Goodness of Fit digunakan untuk memvalidasi performa gabungan antara inner model dan outer model. Nilai Goodness of Fit diperoleh dari:

$$
\begin{aligned}
\text { GoF } & =\sqrt{\operatorname{Com} x R^{2}} \\
& =\sqrt{ }(0,599)(0,6650) \\
& =\sqrt{0,3983} \\
\text { GoF } & =0,6311
\end{aligned}
$$

Hasil perhitungan nilai GoF menunjukkan angka 0,6311. Hasil nilai GoF tersebut lebih besar dari 0,36. Sehingga dapat disimpulkan bahwa model penelitian ini memiliki kemampuan yang tinggi dalam menjelaskan data empiris.

\section{Hasil Uji Hipotesis}

Hasil dari hipotesis yang diajukan dapat dilihat dari besarnya t-statistik. Nilai t-statistik dibandingkan dengan nilai t-tabel yang ditentukan dalam penelitian ini yaitu sebesar 1,9949, di mana diketahui nilai df sebesar 69 (jumlah sampel dikurang dua: 71-2) dan $a$ sebesar 0,05 (two tailed). Batasan yang digunakan untuk menerima atau menolak hipotesis yang diajukan adalah $\pm 1,9949$, yang mana apabila nilai dari t-statistik berada pada rentang nilai -1,9949 dan 1,9949 maka hipotesis akan ditolak atau dengan kata lain menerima hipotesis nol $\left(\mathrm{H}_{0}\right)$. Berikut ini adalah hasil uji hipotesis penelitian:

Tabel 3 Path Coefficients (Mean, STDEV, T-Value)

\begin{tabular}{cccccccc}
\hline & & & $\begin{array}{c}\text { Original } \\
\text { Sample (0) }\end{array}$ & $\begin{array}{c}\text { Sample } \\
\text { Mean (M) }\end{array}$ & $\begin{array}{c}\text { Standard } \\
\text { Deviation } \\
\text { (STDEV) }\end{array}$ & $\begin{array}{c}\text { T-Statistic (IO/ } \\
\text { stdev) }\end{array}$ & P Value \\
\hline $\mathbf{O J}$ & $\rightarrow$ & WI & $-0,005$ & 0,006 & 0,146 & 0,033 & 0,947 \\
$\mathbf{R}$ & $\rightarrow$ & WI & 0,679 & 0,663 & 0,679 & 6,790 & 0,000 \\
$\mathbf{O J} \rightarrow$ & $\rightarrow$ & $\mathbf{E F}$ & 0,054 & 0,063 & 0,067 & 1,235 & 0,217 \\
$\mathbf{R}$ & $\rightarrow$ & $\mathbf{E F}$ & 0,153 & 0,137 & 0,081 & 1,883 & 0,06 \\
$\mathbf{W I}$ & $\rightarrow$ & $\mathbf{E F}$ & 0,802 & 0,812 & 0,064 & 12.568 & 0,000 \\
\hline
\end{tabular}

Sumber: hasil olahan data

Hasil yang tertera pada tabel 3 menunjukkan bahwa pengaruh OJ (organizational justice) terhadap WI (whistleblowing intention) sebesar -0,005 dan tidak signifikan pada 
$0,05(0,033<1,9949)$. Pengaruh $\mathrm{R}$ (religiosity) terhadap WI (whistleblowing intention) sebesar 0,679 dan signifikan pada 0,05 (6,790>1,9949). Pengaruh 0J (organizational justice) terhadap EF (employee fraud) sebesar 0,054 dan tidak signifikan pada 0,05 $(1,235<1,9949)$. Pengaruh R (religiosity) terhadap EF (employee fraud) sebesar 0,153 dan tidak signifikan pada 0,05 (1883>1,9949). Pengaruh WI (whistleblowing intention) terhadap EF (employee fraud) sebesar 0,802 dan signifikan pada 0,05 (12,568>1,9949).

\section{Hasil Uji Efek Intervening}

Langkah pertama yang dilakukan dalam prosedur pengujian intervening adalah dengan melakukan pengujian tidak langsung variabel $\mathrm{X}$ ke variabel $\mathrm{Y}$ melalui variabel $\mathrm{M}$, dengan rumus:

$$
\mathrm{Sab}=\sqrt{\mathrm{b}^{2}} \mathrm{Sa}^{2}+\mathrm{a}^{2} \mathrm{Sb}^{2}+\mathrm{Sa}^{2} S \mathrm{~b}^{2}
$$

Langkah kedua melakukan pengujian untuk mengetahui signifikansi pengaruh tidak langsung dengan menghitung nilai $t$ dari koefisien ab dengan rumus:

$$
\mathrm{t}=\frac{\mathrm{ab}}{\mathrm{Sab}}
$$

Hasil uji efek intervening disajikan pada tabel berikut:

\begin{tabular}{|c|c|c|c|c|c|}
\hline & & & & & t-statistik \\
\hline OJ & $\rightarrow$ & WI & $\rightarrow$ & $\mathrm{EF}$ & $-0,0341$ \\
\hline $\mathrm{R}$ & $\rightarrow$ & WI & $\rightarrow$ & $\mathrm{EF}$ & 5,9553 \\
\hline
\end{tabular}

Tabel 4 Hasil Uji Efek Intervening

Sumber: hasil olahan data

Hasil dari pengujian melalui uji sobel dapat diketahui dengan t-hitung signifikan pada 0,05 yaitu $-0,0341<1,9949$. Sehingga dapat disimpulkan bahwa tidak terdapat pengaruh intervening variabel whistleblowing intention pada hubungan tidak langsung variabel organization justice dan employee fraud. Sedangkan untuk hasil dari religiosity, t-hitung signifikan pada 0,05 yaitu 5,9553>1,9949. Sehingga dapat disimpulkan bahwa terdapat pengaruh intervening variabel whistleblowing intention pada hubungan tidak langsung variabel religiosity dan employee fraud.

\section{Pengaruh Organizational Justice Terhadap Whistleblowing Intention}

Hasil dari pengujian menunjukkan nilai t-statistik sebesar 0,033. Nilai tersebut lebih kecil daripada nilai t-tabel yaitu 1,9949. Hal ini berarti bahwa hipotesis pertama (Ha1) ditolak. Hasil penelitian ini menunjukkan bahwa tidak berpengaruhnya organizational justice terhadap whistleblowing intention dikarenakan justifikasi mengenai organizational justice pada setiap karywan berbeda-beda. Konsep keadilan organisasi adalah konsep psikologis di mana karyawan menentukan apakah mereka telah diperlakukan secara adil dalam pekerjaan mereka. Hal tersebut mengisyaratkan bahwa konsep keadilan itu 
sendiri belum bisa disamakan persepsinya bagi setiap individu. Persepsi keadilan menurut tiap-tiap individu dapat berbeda satu sama lain. Hal ini juga didukung dengan theory of planned behavior berdasarkan subjective norm yang menyatakan bahwa perlakuan mengenai keadilan yang diberikan oleh organisasi terhadap karyawannya dapat membuat karyawan terdorong maupun terhambat dalam mengungkapkan tindakan pelanggaran sesuai dengan justifikasi dan persepsi dari masing-masing karyawan. Hasil penelitian ini sejalan dengan hasil penelitian yang dilakukan oleh Wulansari (2019) yang menunjukkan hasil yang sama.

\section{Pengaruh Religiosity Terhadap Whistleblowing Intention}

Hasil pengujian menunjukkan nilai t-statistik sebesar 6,790. Nilai tersebut lebih besar daripada nilai t-tabel yaitu 1,9949, sehingga hipotesis kedua (Ha2) diterima. Hasil tersebut sesuai dengan pernyataan bahwa agama merupakan motivasi bagi individu untuk melakukan suatu tindakan yang dianggap memiliki unsur kemurnian dan kepatuhan. Seseorang yang memiliki sifat religiusitas akan berperilaku sesuai dengan nilai-nilai agamanya dan tidak akan menyetujui perilaku ataupun tindakan yang tidak sesuai dengan prinsip-prinsip kepercayaan yang dianutnya, sehingga ketika dihadapkan pada kondisi yang tidak sesuai dengan etika maka akan cenderung melaporkan tindakan yang melanggar tersebut. Individu dengan nilai religiusitas yang tinggi akan merasa tidak nyaman saat melihat hal yang menyimpang terjadi di lingkungannya. Sehingga hal tersebut mengarah kepada niat untuk melaporkan pelanggaran. Hasil penelitian ini sejalan dengan penelitian yang dilakukan oleh Alfie, (2019); Puni et al., (2016); Puspitosari, (2019).

\section{Pengaruh Organizational Justice Terhadap Employee Fraud}

Hasil pengujian menunjukkan bahwa nilai t-statistik sebesar 1,235. Nilai tersebut lebih kecil daripada nilai t-tabel yaitu 1,9949. Sehingga hipotesis ketiga (Ha3) ditolak. Hasil penelitian ini dapat disebabkan karena persepsi mengenai keadilan menurut seseorang belum tentu sama dengan yang lain. Persepsi ini bersifat subjektif, karena rasa adil pada tiap individu dapat diartikan berbeda-beda. Selain itu, sejalan dengan yang dikemukakan oleh Bologna (1993) bahwa tindakan fraud tetap saja dapat terjadi karena adanya faktor keserakahan yang dimiliki oleh setiap individu. Adanya sifat serakah dan tidak merasa puas menjadikan seseorang tidak menyadari apa hakikat keadilan itu sendiri. Individu seperti ini akan terus merasa tidak puas dengan apa yang didapatkan sehingga melakukan tindakan kecurangan guna memenuhi keinginannya, sehingga usaha untuk menerapkan keadilan organisasi yang tinggi pun belum mampu mencegah seseorang untuk melakukan fraud. Hasil penelitian ini sejalan dengan hasil penelitian yang dilakukan oleh Pristiyanti (2012) dan I. Indriani et al., (2016).

\section{Pengaruh Religiosity Terhadap Employee Fraud}

Hasil pengujian menunjukkan nilai t-statistik sebesar 1,883. Nilai tersebut lebih kecil daripada nilai t-tabel yaitu 1,9949. Sehingga hipotesis keempat (Ha4) ditolak. 
Hasil ini mengindikasikan bahwa individu yang memiliki religiusitas yang tinggi tidak menutup kemungkinan melakukan kecurangan. Hasil temuan penelitian ini sesuai dengan fenomena kecurangan terjadi di Indonesia. Seperti yang seringkali diberitakan di media masa bahwa pelaku kecurangan seringkali bukan individu yang terlihat religiusitasnya rendah. Oleh karena itu seseorang yang memiliki religiusitas yang tinggi tidak dapat menjamin ia tidak akan melakukan kecurangan kecurangan. Apalagi jika individu tersebut berada dalam tekanan (pressure) yang dapat mendorongnya melakukan tindakan fraud.

\section{Pengaruh Whiatleblowing Intention Terhadap Employee Fraud}

Hasil pengujian menunjukkan nilai t-statistik sebesar 12,568. Nilai tersebut lebih besar daripada nilai t-tabel yaitu 1,9949. Sehingga hipotesis kelima (Ha5) diterima. Hasil ini sesuai dengan unsur fraud pentagon theory yaitu opportunity (kesempatan). Kesempatan seseorang dalam melakukan fraud dapat diminimalisir dengan adanya pengawasan dari masing-masing karyawan yang ada di perusahaan. Setiap pegawai akan merasa diawasi oleh pegawai lainnya sehingga dapat meminimalisir fraud. Selain itu, terdapat juga beberapa payung hukum yang dapat melindungi seorang whistleblower dalam mengungkapkan tindakan kecurangan antara lain dalam UU Nomor 13 Tahun 2006 tentang perlindungan saksi dan korban telah menjelaskan bagaimana perlindungan terhadap seorang whistleblower. Adanya perlindungan hukum ini juga dapat diasumsikan sebagai alasan mengapa karyawan cenderung memiliki niat untuk melakukan whistleblowing.

\section{Pengaruh Organizational Justice Terhadap Employee Fraud Dengan Whistleblowing Intention Sebagai Variabel Intervening}

Pengujian hipotesis yang dilakukan dengan metode uji sobel menunjukkan nilai t-hitung signifikan pada 0,05 yaitu $-0,0341<1,9949$. Sehingga hipotesis keenam (Ha6) ditolak. Hasil penelitian ini menunjukkan bahwa whistleblowing intention tidak bisa memediasi hubungan antara organizational justice dengan employee fraud. Hal tersebut menunjukkan bahwa persepsi keadilan organisasi yang ada pada diri karyawan belum mampu mendorong karyawan untuk memiliki niat untuk melakukan tindakan whistleblowing dan meminimalisir kecurangan karyawan di perusahaan. Hal ini dikarenakan persepsi mengenai keadilan pada tiap karyawan pun berbeda-beda. Selain itu, perasaan tidak pernah puas yang dimiliki oleh manusia pun dapat medorong seseorang melakukan fraud, walaupun imbalan yang diberikan telah sesuai dengan pekerjaan yang dilakukan. Hal tersebut sesuai dengan theory of planned behavior yang menyatakan persepsi atau sudut pandang seseorang dalam melihat suatu objek berbeda antara satu orang dengan orang yang lain sehingga mereka dapat mencari pembenaran dari dalam diri sebelum melakukan suatu perilaku. 


\section{Pengaruh Religiosity Terhadap Employee Fraud Dengan Whistleblowing Intention Sebagai Variabel Intervening}

Pengujian hipotesis yang dilakukan dengan metode uji sobel menunjukkan nilai t-hitung signifikan pada 0,05 yaitu 5,9553 > 1,9949. Sehingga hipotesis ketujuh (Ha7) diterima. Hasil penelitian ini menunjukkan bahwa semakin tingginya religiusitas pada diri seseorang dapat meningkatkan niat seseorang untuk melakukan tindakan whistleblowing yang kemudian berdampak pada berkurangnya kecenderungan seseorang dalam melakukan tindakan kecurangan (fraud). Hasil ini juga sesuai dengan syariah enterprise theory yang menempatkan Tuhan merupakan stakeholder utama, tindakan yang dilakukan terhadap organisasi pertanggungjawabannya bukan hanya ke perusahaan atau pun shareholder, namun utamanya adalah kepada Allah. Weibe dan Fleck (1980) dalam Puspitosari (2019) menyatakan bahwa standar moral yang tinggi, disiplin, dan tanggung jawab cenderung diperoleh oleh seseorang yang menerima agama sebagai fokus utama kehidupan mereka dibandingkan dengan orang yang tidak beragama. Oklesehan dan Hoyt (1996) juga menyatakan bahwa orientasi keagamaan seseorang akan mempengaruhi penalaran moralnya. Oleh karena itu, individu dengan nilai religiusitas tinggi akan merasa tidak nyaman ketika mereka melihat penyimpangan di lingkungannya sehingga mengarah kepada niat melakukan whistleblowing yang kemudian dapat meminimalisir tindakan fraud.

\section{SIMPULAN}

Penelitian ini dilakukan untuk meneliti faktor-faktor yang dapat mempengaruhi karyawan dalam melakukan tindakan employee fraud. Penelitian ini bertujuan untuk mengetahui pengaruh organizational justice dan religiosity karyawan dalam melakukan kecurangan dengan dimediasi oleh whistleblowing intention. Total sampel penelitian yaitu 71 karyawan bank syariah yang bekerja di wilayah DKI Jakarta. Berdasarkan hasil penelitian menggunakan SmartPLS 3.0 menunjukkan adanya hubungan yang signifikan antara religiosity terhadap whistleblowing intention, sedangkan organizational justice tidak berpengaruh secara signifikan terhadap whistleblowing intention. Whistleblowing intention berpengaruh secara signifikan terhadap employee fraud, namun organizational justice dan religiosity tidak berpengaruh secara signifikan terhadap employee fraud. Religiosity berpengaruh terhadap employee fraud dengan dimediasi oleh whistleblowing intention, sedangkan organizational justice tidak berpengaruh secara signifikan terhadap employee fraud dengan dimediasi oleh whistleblowing intention.

Penelitian ini memiliki beberapa keterbatasan. Pertama penelitian ini hanya terbatas pada penggunaan kuesioner dengan penelitian secara persepsi pribadi, tanpa adanya wawancara secara langsung. Kedua, peneliti tidak dapat menyebarkan kuesioner fisik dari kantor ke kantor, melainkan menggunakan Google Form, hal ini dikarenakan situasi pandemik Covid-19 tidak memungkinkan untuk penyebaran kuesioner secara langsung. Temuan hasil penelitian ini berkontribusi dalam memperluas pengetahuan di bidang employee fraud. Temuan diharapkan dapat bermanfaat bagi pihak terkait termasuk pembuat kebijakan, pengelola bank serta praktisi dalam meningkatkan keamanan terhadap 
tindakan pencegahan employee fraud. Selain itu penelitian ini juga dapat dijadikan referensi untuk penelitian-penelitian selanjutnya mengenai topik employee fraud.

\section{PUSTAKA ACUAN}

ACFE. (2020). Report To The Nations: Global Study On Occupational Fraud and Abuse.

Bagustianto, R., \& Nurkholis. (2015). Faktor-Faktor Yang Mempengaruhi Minat Pegawai Negeri Sipil (PNS) Untuk Melakukan Tindakan Whistle-Blowing (Studi Pada PNS BPK RI). E-Journal Universitas Brawijaya.

Balogun, S. K., Selemogwe, M., \& Akinfala, F. (2013). Fraud and Extravagant Life Styles Among Bank Employees: Case of Convicted Bank Workers in Nigeria. Psychological Thought, 6(2), 252-263. https://doi.org/10.5964/psyct.v6i2.68

Bologna, J. (1993). Handbook on corporate fraud: Prevention, detection, and investigation. Butterworth-Heinemann.

Fathi, W. N. I. W. M., Ghani, E. K., Said, J., \& Puspitasari, E. (2017). Potential Employee Fraud Scape in Islamic Banks: The Fraud Triangle Perspective. Search Results Web Results Global Journal Al-Thaqafah GJAT, 7(2), 79-94.

Fauzi, Y. (2020). OJK Kesulitan Deteksi Fraud Perbankan oleh Karyawan. Cnnindonesia.Com.

Ghozali, I. (2015). Konsep, Teknik, dan Aplikasi Menggunakan Program Smart PLS 3.0 (2nd ed.). Semarang: Salemba Empat, Universitas Diponegoro.

ICD-Refinitif. (2019). Islamic Finance Development Report 2019.

Jensen, M. C., \& Meckling, W. H. (1976). Theory Of The Firm : Managerial Behavior, Agency Costs And Ownership Structure. Journal of Financial Economics 3, 3, 305-360.

KPMG. (2013). Integrity Survey 2013.

Kristanto, H. (2015). Keadilan Organisasional, Komitmen Organisasional, dan Kinerja Karyawan. Jurnal Manajemen Dan Kewirausahaan, 17(1), 86-98.

Kurniawan, A., Utami, I., Ade, D., Ashedica, C., Kristen, U., \& Wacana, S. (2018). Organizational Justice and Whistleblowing: An Experimental Test. Jurnal Akuntansi Dan Keuangan, 20(2), 73-78. https://doi.org/10.9744/jak.20.2.73-78

Lutfi, \& Biduri, S. (2014). Apakah Organization Culture Dan Whistleblowing Berpengaruh Terhadap Fraud? Prospek Dan Tantangan Pengelolaan Keuangan Desa.

Olanrewaju, R. A., \& Johnson-Rokosu, S. (2019). Impact of Employee Fraud on Business Entities in Nigeria. International Journal of Research and Innovation in Social Science, 3(11), 41-50.

Otoritas Jasa Keuangan. (2019). Statistik Perbankan Syariah (SPS).

Pamungkas, I. D. (2014). Pengaruh Religiusitas dan Rasionalisasi Dalam Mencegah dan Mendeteksi Kecenderungan Kecurangan Akuntansi. Jurnal Ekonomi Dan Bisnis, 15(2), 48-59.

Pristiyanti, I. R. (2012). Persepsi Pegawai Instansi Pemerintah Mengenai Faktor-Faktor Yang Mempengaruhi Fraud Di Sektor Pemerintahan. Accounting Analysis Journal, 1(1). 
Puni, A., Agyemang, C. B., \& Asamoah, E. S. (2016). Religiosity, Job Status and WhistleBlowing : Evidence from Micro-Finance Companies. International Journal of Business and Social Research, 06(02), 38-47.

Purdwiastuti, M. M., \& Nofiyanti, R. (2012). Biaya Keagenan dan Kebijakan Deviden: Implikasi Afiliasi Grup Bisnis. UG Journal.

Puspitosari, I. (2019). Whistleblowing Intention Sebagai Bagian Dari Etika Islam Ditinjau Dari Intensitas Moral, Orientasi Etika Relativisme dan Religiusitas. Jurnal Iqtisaduna, 5(2), 139-152. https://doi.org/10.24252/iqtisaduna.v5i2.10701

Rae, K., \& Subramaniam, N. (2008). Quality Of Internal Control Procedures Antecedents And Moderating Effect On Organisational Justice And Employee Fraud. Managerial Audit- Ing Journal, 23(2), 104-124. https://doi.org/10.1108/02686900810839820

Said, J., Alam, M. M., Ramli, M., \& Rafidi, M. (2017). Integrating ethical values into fraud triangle theory in assessing employee fraud: Evidence from the Malaysian banking industry. Journal of International Studies, 10(2), 170-184. https://doi.org/10.14254/20718330.2017/10-2/13

Said, J., Karim, Z. A., \& Johari, R. J. (2018). Integrating religiosity into fraud triangle theory: findings on Malaysian police officers. Journal of Criminological Research, Policy and Practice, 4(2), 111-123. https://doi.org/10.1108/JCRPP-09-2017-0027

Sanusi, Z. M., Rameli, M. N. F., \& Isa, Y. M. (2015). Fraud Schemes in the Banking Institutions : Prevention Measures to Avoid Severe Financial Loss. Procedia Economics and Finance, 28(April), 107-113. https://doi.org/10.1016/S2212-5671(15)01088-6

Situmorang, A. P. (2018). Kata Sri Mulyani soal Peranan Perbankan dalam Mendorong Ekonomi RI. Liputan6.Com.

Soni, F., Maroun, W., \& Padia, N. (2015). Perceptions of justice as a catalyst for whistleblowing by trainee auditors in South Africa. Meditari Accountancy Research, 23(1), 118-140.

Sumbayak, J. S. (2017). Pengaruh Keadilan Organisasi, Sistem Pengendalian Intern, Komitmen Organisasi Dan Gaya Kepemimpinan Terhadap Kecurangan (Fraud). JOM Fekon, 4(1).

Triyuwono, I. (2011). Mengangkat “Sing Liyan” Untuk Formulasi Nilai Tambah Syari'ah. Jurnal Akuntansi Multiparadigma, 2(2), 186-368. https://doi.org/http://dx.doi.org/10.18202/ jamal.2011.08.7116

Ugaddan, R. G., \& Park, S. M. (2018). Do Trustful Leadership, Organizational Justice, and Motivation Influence Whistle- Blowing Intention? Evidence From Federal Employees. Public Personnel Management, 1 -26. https://doi.org/10.1177/0091026018783009

Utari, N. M. A. D., Sujana, E., \& Yuniarta, A. (2019). Pengaruh Efektivitas Pengendalian Internal, Moralitas Individu, Dan Whistleblowing Terhadap Kecenderungan Kecurangan (Fraud) Pada Lembaga Perkreditan Desa Di Kecamatan Buleleng. Jurnal Akuntansi Profesi, 10(2).

Wolfe, D. T., \& Hermanson, D. R. (2004). The Fraud Diamond: Considering the Four Elements of Fraud. CPA Journal, 74(12), 38-42. 
Yuliana, A. (2016). Pengaruh Keadilan Organisasi, Sistem Pengendalian Intern Dan Komitmen Organisasi Terhadap Kecurangan (Fraud). JOM Fekon, 3(1).

Zamzam, I., Mahdi, S. A., \& Ansar, R. (2017). Pengaruh Diamond Fraud Dan Tingkat Religiuitas Terhadap Kecurangan Akademik (Studi Pada Mahasiswa S-1 Di Lingkungan Perguruan Tinggi Se Kota Ternate). Jurnal Ilmiah Akuntansi Peradaban, 3(2), 1-24. 